\title{
A JURISDIÇÃO CONSTITUCIONAL E A DEFESA DA CONSTITUIÇÃO
}

\author{
Maria Celeste Cordeiro Leite dos Santos* \\ Marilene Araujo**
}

RESUMO

A Constituição é a lei que rege a vida em comunidade. É a partir da Constituição que se busca a unidade do Direito. Sua importância conduz a debates, como saber quem é o "soberano que diz o que a Constituição diz". Hans Kelsen considerou que um órgão técnico deveria

\footnotetext{
* Professora Associada pela USP, Livre Docente em Direito Penal pela USP, Doutora em Filosofia e Teoria Geral do Direito pela PUC/SP, Pós Doutora em Psicologia pela PUC/SP, Professora dos Programas de Pós Graduação em Direito (Mestrado e Doutorado) e da Graduação em Direito da PUC/ SP, Mestre em Direito Penal pela PUC/SP, Mestre em Filosofia pela PUC/ SP, Coordenadora e líder do Grupo de Pesquisas em Direito: "Percepções Cognitivas na Interpretação da Norma”, da Pontifícia Universidade Católica de São Paulo, credenciado pelo CNPQ, membro titular do Instituto dos Advogados de São Paulo, IASP, membro titular da CAASP, membro do Instituto Brasileiro de Direito de Família, IBDFAM, membro do Instituto Brasileiro de Ciências Criminais, IBCcrim, membro titular da Comissão Internacional de Bioética, Membro Titular da Associação Internacional de Direito Penal (Paris- França), membro do Instituto Internacional de Filosofia do Direito, membro fundador da Comissão de Bioética e Biodireito da OAB/SP, membro fundador da Comissão de Bioética no Conselho Federal da OAB/Brasil, Professora das disciplinas de Filosofia do Direito, Sociologia Jurídica, Teoria Geral do Direito, Questões Interdisciplinares da Ciência do Direito, Ética, Bioética, Biodireito, Direito, Justiça e Linguagem, Monografia Jurídica na PUC/SP.

**Doutoranda em Filosofia do Direito PUC/SP. Mestra em Direito Constitucional pela PUC/SP. Especialista em Direito Administrativo PUC/SP. Especialista em Processo Civil pela Escola Superior da Procuradoria Geral do Estado de São Paulo. Membra do IBDC - Instituto Brasileiro de Direito Constitucional. Membro do Grupo de Pesquisa Percepções Cognitivas na Interpretação da Norma. Advogada
} 
manter a função de proteger e defender a Constituição, denominando tal aparato de jurisdição constitucional. O modelo de jurisdição constitucional proposto por Kelsen foi absorvido por vários países do ocidente. Agora, novo desafio ocorre, é tornar a jurisdição constitucional plural e manter a sua função de proteção e defesa da Constituição.

Palavras-chave: Constituição. Defesa. Jurisdição Constitucional. Pluralismo.

\section{ABSTRACT}

The Constitution is the law that governs life in community. It is from the Constitution that we seek the unity of law. Its importance leads to debates, such as knowing who is the sovereign who says what the Constitution says. Hans Kelsen considered that the technical body should maintain the function of protecting and defending the Constitution, calling such an apparatus of constitutional jurisdiction. The model of constitutional jurisdiction proposed by Kelsen has been absorbed by several countries in the West. Now, a new challenge is to make constitutional jurisdiction plural and maintain its function of protecting and defending the Constitution.

Keywords: Constitution. Defense. Constitutional Jurisdiction.Pluralism.

\section{A JURISDIÇÃO CONSTITUCIONAL E A PROTEÇÃO À CONSTITUIÇÃO}

\subsection{A CONSTITUIÇÃO}

A Constituição, para Hans Kelsen, está ligada à noção de hierarquia das normas e a um princípio que determina o ordenamento jurídico e a essência da comunidade constituída por este ordenamento. Para Kelsen, a Constituição é "o fundamento do Estado e a base do ordenamento jurídico” Aqui há lugar ao princípio "que expressa juridicamente as forças politicas em um determinado momento". 


\section{DA DISTINÇÃO ENTRE FILOSOFIA DO DIREITO E CIÊNCIA JURÍDICA}

A Constituição é a norma que traça e regula os parâmetros da elaboração das leis, das normas gerais de execução - por onde se exerce as atividades dos órgãos estatais, como os tribunais e a administração pública. Nas palavras do jurista austríaco:

"a Constituição é, pois a base indispensável das normas jurídicas que regulam a conduta recíproca dos membros da coletividade estatal, assim como daqueles que determinam os órgãos necessários para aplicá-las e impô-las, e a forma como estes órgãos haverão de proceder. É dizer, a Constituição é o assento fundamental do ordenamento estatal" ${ }^{1}$.

A importância da Constituição frente ao sistema jurídico e ao sistema politico é explicitada por vários autores, a partir dos conceitos atribuídos por eles ao texto maior. Sem dúvida, a Constituição traz o fenômeno da constitucionalização do poder. Para Konrad Hesse, a Constituição é "a ordem jurídica fundamental da comunidade" 2 . Já Canotilho considera que a "Constituição é o estatuto jurídico do fenômeno político 3 ".

A Constituição, para Luhmann, é a forma que, mediante o sistema jurídico, rege própria autonomia do Direito. O Direito é a unidade da diferença de dois tipos de texto: o direito constitucional e o outro direito. A Constituição conduz ao acoplamento estrutural entre o sistema jurídico e o sistema politico.

Neste sentido, Niklas Luhmann traz a conceituação da Constituição.

O conceito de Constituição, contrariamente ao que parece à primeira vista, é uma reação à diferenciação entre direito

1 HANS. Kelsen. La garantía jurisdiccional de la Constitución (la justicia constitucional). Revista Iberoamericana de Derecho Procesal Constitucional núm. 10, julio-diciembre 2008, p. 3-46.

2 HESSE, Konrad. Escritos de derecho constitucional. Madrid: Centro de Estudos Constitucionales, 1983. p. 16.

3 CAnotilho, José Joaquim Gomes. Direito Constitucional e Teoria da Constituição. Coimbra: Livraria Almedina. Ed. 3 ${ }^{\mathrm{a}}, 1998$. 
e política, ou dito com uma ênfase ainda maior, à total separação de ambos os sistemas de funções e à consequente necessidade de uma religação entre eles ${ }^{4}$.

A Constituição é que permite o acoplamento estrutural entre o sistema jurídico e o sistema político. Ao mesmo tempo, ela produz a unidade do Direito a partir da diferenciação do direito constitucional e do outro direito. É a unidade do Direito codificado em lícito/não lícito.

\subsection{QUEM É O GUARDiÃO DA CONSTITUIÇÃO}

Debate ocorrido durante os anos 30 do século XX, entre Kelsen e Carl Schmitt, consiste em determinar quem é o guardião da Constituição. Em 1931, Schmitt escreve o livro "O guardião da Constituição". Logo em seguida, é a vez de Kelsen dissertar, em sua obra, "Quem deve ser o guardião da Constituição".

Em termos simplórios, pode-se dizer que Kelsen considera que o guardião da Constituição deve ser um Tribunal de Justiça Constitucional, enquanto Schmitt considera que o guardião é o presidente.

Enquanto para Kelsen a Constituição é uma norma cuja existência e validade apoiam todo o ordenamento jurídico, de forma escalonada, sendo ela a própria "garantia de paz política no interior do Estado"; Schmitt considera que a Constituição é uma decisão política, ou seja, consiste em um elemento de pura decisão, sem derivação normativa. Para ele,

4 A Constituição como Aquisição Evolutiva. Tradução realizada a partir do original ("Verfassung als evolutionäre Errungenschaft". In:Rechthistorisches Journal. Vol. IX, 1990, pp. 176 a 220), cotejada com a tradução italiana de F. Fiore ("La costituzione come acquisizione evolutiva".In: ZAGREBELSKY, Gustavo. PORTINARO, Pier Paolo. LUTHER, Jörg. Il Futuro della Costituzione. Torino: Einaudi, 1996), por Menelick de Carvalho Netto, Giancarlo Corsi e Raffaele De Giorgi. Notas de rodapé traduzidas da versão em italiano por Paulo Sávio Peixoto Maia (texto não revisado pelo tradutor). Disponivel em http://pt.scribd.com/doc/31253250/LUHMANN-Niklas-Aconstituicao-como-aquisicao-evolutiva. Acessado em 12.06.2014. 


\section{DA DISTINÇÃO ENTRE FILOSOFIA DO DIREITO E CIÊNCIA JURÍDICA}

a solução de Kelsen traz uma "politização da justiça" mais do que a "judicialização da política".

Cabe esclarecer que, segundo Schmitt, a Constituição dispõe sobre a existência política do Estado, sendo forma de unidade política. Ainda, Schmitt distingue a Constituição - entendida como uma decisão sobre a existência política de um Estado, como sendo forma substancial da unidade - da lei constitucional.

Esta última (a lei constitucional) é uma simples realização normativa, que pressupõe a Constituição política como seu fundamento ${ }^{5}$. Assim, apenas em países, chamados pelo autor de Estados de jurisdição - onde não existem normas que obriguem o juiz, no sentido existente em outros países denominados de Estado legislativo - é que se pode falar em tribunal constitucional ${ }^{6}$.

\subsection{A PROTEÇÃO DA CONSTITUIÇÃO}

Para Hans Kelsen, a jurisdição constitucional consiste em um elemento de caráter técnico do sistema que objetiva assegurar o exercício regular das funções estatais. As funções

5 HERRERA. Carlos Miguel. La polémica Schmitt-Kelsen sobre el guardián de la constitución. Disponivelhttp://www.udea.edu.co/portal/page/portal/bibliotecaSedesDependencias/unidadesAcademicas / Acessado em 04/05/2014

6 En un Estado de jurisdicción (como los Estados Unidos) puede existir una Corte de Justicia como guardián de la Constitución en la medida que no existen normas que obligen al juez a subordinar su decisión. Por el contrario, en un Estado legislativo no puede haber "justicia constitucional", ya que la justicia no decide por ella sola, sino a través de las normas que le dicta el Parlamento, a las cuales está subordinada. En un Estado legislativo, por tanto, sería el Parlamento el guardián de la Constitución, en tanto representante de la unidad de la nación frente al monarca, y la defensa de la Constitución se realiza frente a los eventuales abusos del Ejecutivo. HERRERA. Carlos Miguel. La polémica Schmitt-Kelsen sobre el guardián de la constitución.Disponívelhttp://www.udea.edu.co/portal/ page/portal/bibliotecaSedesDependencias/unidadesAcademicas/ Acessado em 04/05/2014. 
estatais $^{7}$ são atos jurídicos, portanto, atos que criam direitos, verdadeiras normas jurídicas vigentes ${ }^{8}$.

É a jurisdição constitucional que garante a eficácia e a aplicação da Constituição, bem como a sua obrigatoriedade. Para Kelsen, a jurisdição constitucional tem como objetivo a proteção da Constituição.

A jurisdição constitucional, na visão kelseniana, é instrumento de proteção das minorias. É o caso, por exemplo, das minorias parlamentares que acabam- diferentemente do que ocorre no processo de alteração constitucional, onde de modo geral há quórum qualificado - sendo tolhidas pela maioria simples. Também as minorias muitas vezes são aleijadas de direitos como acesso, igualdade, dentre outros direitos fundamentais.

A jurisdição constitucional assegura ainda, nos países federativos, o princípio da federação, uma vez que as regras de descentralização e as regras que determinam as competências entre os entes federados e a federação são regradas pela Constituição.

7 Kelsen considera: a) não há três, mas apenas duas funções infra e supra-ordenadas (criação e aplicação do direito); b) a legislação é o resultado de uma interação dos poderes e não o monopólio do legislativo. c) existe "função legislativa do judiciário quando os Tribunais anulam leis inconstitucionais e, em segundo lugar, quando no sistema de common law há o estabelecimento de precedentes que podem definir conteúdo e o próprio sentido das leis de forma e até de maneira diversa do órgão legislador"; d) O que existe não é uma separação de poderes e sim uma atribuição de poderes, o Poder Legislativo como órgão legislador compartilha a sua competência com o judiciário e o executivo. PEIXINHO, Manoel Messias. O Princípio da Separação dos Poderes, a Judicialização da Politica e Direitos Fundamentais. Revista de Direitos e Garantias Fundamentais, Vitória, n.4, p.13-14, jul/dez.2008.

8 HANS. Kelsen. La garantía jurisdiccional de la Constitución (la justicia constitucional). Revista Iberoamericana de Derecho Procesal Constitucional núm. 10, julio-diciembre 2008, pp. 3-46.

8 - Revista do Curso de Direito da Faculdade de Humanidades e Direito, v. 14, n. 14, 2017 


\section{DA DISTINÇÃO ENTRE FILOSOFIA DO DIREITO E CIÊNCIA JURÍDICA}

\subsection{JURISDIÇÃO CONSTITUCIONAL E A QUESTÃO DA INDEPENDENCIA}

Paulo Bonavides esclarece que o conceito de jurisdição constitucional necessita de "uma instância neutra, mediadora e imparcial na solução dos conflitos constitucionais". A independência dos juízes, na aplicação do direito, ganha contornos paradoxais e de difícil verificação em se tratando de jurisdição constitucional.

Afinal, conforme assevera Paulo Bonavides "toda a legitimidade em matéria constitucional é mais política que jurídica" e logo em seguida explica que "os tribunais constitucionais declaram o direito, mas ao mesmo passo fazem política”. Para Canotilho "o verdadeiro poder soberano é aquele que decide, em última palavra, sobre a interpretação da lei fundamental ${ }^{10 "}$.

Ao mesmo tempo, a legitimidade das decisões prolatadas no âmbito da jurisdição constitucional é orientada na "acuidade do juiz em orientar-se nas suas sentenças e nas suas diligências hermenêuticas, pela adesão do corpo político aos valores representados e incorporados na Constituição ${ }^{11 "}$.

Explica Luís Roberto Barroso que a doutrina tradicional clama a necessidade de juízes independentes da política, para tanto, os juízes devem estar limitados à aplicação do direito vigente, de acordo com critérios aceitos pela comunidade jurídica ${ }^{12}$.

\footnotetext{
9 BONAVIDES. Paulo Jurisdição constitucional e legitimidade (algumas observações sobre o Brasil) Disponivel http://www.scielo.br/pdf/ea/v18n51/ a07v1851. Acessado em 04/05/2014.

${ }^{10}$ CAnotilho. José Joaquim Gomes. Direito de Acesso à Justiça Constitucional Estados da Conferência das Jurisdições Constitucionais Dos Países de Língua Portuguesa Luanda, Junho de 2011.

${ }^{11}$ BONAVIDES. Paulo Jurisdição constitucional e legitimidade (algumas observações sobre o Brasil) Disponivel http://www.scielo.br/pdf/ea/v18n51/ a07v1851. Acessado em 04/05/2014.

${ }^{12}$ BARROSO. Luís Roberto. Curso de Direito Constitucional Contemporâneo. São Paulo: Saraiva. 2012.
} 
Ademais, lembra o autor a dificuldade de se fazer um governo de leis e não de juízes, citando, deste modo, a observação de Dieter Grimm, ex-juiz da Corte Constitucional alemã:

"a garantia constitucional de independência judicial protege os juízes da política, mas não protege o sistema constitucional e a sociedade dos juízes que, por razões distintas da pressão politica direta, estão dispostos a desobedecer ou distorcer a lei".

Bonavides, em texto intitulado Jurisdição constitucional e legitimidade, datado de 2004, esclarece que há sempre pressões sobre os juízes, principalmente, no caso específico dos países periféricos, onde os sistemas judiciais estão moldados para atender os interesses dos detentores do poder.

Ele cita ainda que "a influência do poder econômico mundial, por meio de suas instituições financeiras internacionais, nos sistemas judiciais dos países pobres, viola a autodeterminação dos povos e a soberania das nações".

Ao se concentrar na questão da jurisdição constitucional do Brasil, o jurista explica que compromete, em certo ponto a legitimidade do Supremo Tribunal Federal, o fato de ele não ser uma corte constitucional, sendo que o exercício de outras competências priva o órgão de concentrar-se no exame das questões constitucionais. Ainda esclarece Paulo Bonavides, sobre a "necessidade de desmembrar do Poder Judiciário a corte de justiça que exerce o papel de guardiã da Constituição".

\section{ANTECEDENTES HISTÓRICOS}

Nos Estados Unidos, a Suprema Corte, em 1803, ao decidir sobre o caso Marbury v. Madison torna totalmente possivel o controle jurisdicional dos poderes politicos em face de uma lei fundamental, a Constituição. O celebrado caso ocorre no século XVII, quando Thomas Jefferson derrota, nas eleições presidências, John Adams.

O grupo derrotado (federalistas) decide dificultar a vida do grupo vencedor (democrata-republicano) e tenta manter o 


\section{DA DISTINÇÃO ENTRE FILOSOFIA DO DIREITO E CIÊNCIA JURÍDICA}

controle do Estado. Para tanto, aprova e sanciona uma nova lei judiciária, que cria inúmeros cargos de juízes.

John Adams nomeia vários juízes na véspera da posse de Thomas Jefferson, que são apelidados de "juízos da meia noite". É nomeado para juiz de paz do Distrito de Colúmbia, William Marbury. Entretanto, depois o secretário de Thomas Jerfferson, James Madison, seguindo as instruções do novo presidente, se nega a dar posse ao recém-nomeado juiz Marbury.

O recém-nomeado juiz requer um writ junto a Suprema Corte exigindo a sua diplomação e a sua posse. O caso é relatado pelo presidente da Suprema Corte John Marshall.

O Tribunal decide evitar o confronto com o Poder Executivo. Afirma o Tribunal que Madison comete ilegalidade ao negar a posse a Marbury e que o instrumento hábil para combater tal ato é o writ.

Entretanto, a Constituição delimita as competências originárias da Suprema Corte e o rol de competência não estabelece a competência à Suprema Corte para conhecer originariamente writ.

Deste modo, as competências da Suprema Corte não podem ser modificadas por uma lei. No caso em comento, a lei judiciária, datada de 1789, em seu artigo 13, confere ao Supremo Tribunal a competência originária para conhecer ordem de mandamus.

A Suprema Corte decide que uma lei que repugna à Constituição é nula ${ }^{13}$. Este é o primeiro caso jurisprudencial que traz o controle de constitucionalidade da lei e a supremacia da Constituição.

\footnotetext{
13 "Thus, the particular phraseology of the constitution of the United States confirms and strengthens the principle, supposed to be essential to all written constitutions, that a law repugnant to the constitution is void; and that courts, as well as other departments, are bound by that instrument" WILLIAM MARBURY v. JAMES MADISON, Secretary of State of the United States. Supreme Court of the United States 5 U.S. 137 february, 1803. Disponivel http://law2.umkc.edu/faculty/projects/ftrials/conlaw/ marbury.HTML. Acessado em 12 de junho de 2014.
} 
A Constituição austríaca de 1920, em seu artigo 89, proíbe que os tribunais judiciais controlem a constitucionalidade das leis. A mesma Constituição, em seu artigo 140, estabelece que o Tribunal Constitucional é o único autorizado a conhecer as constitucionalidade das leis estatais ${ }^{14}$.

Esta experiência não frutifica na Europa, em razão da implantação dos Estados nazistas e fascistas, ocorrendo que, apenas após o final da II guerra mundial, o modelo de jurisdição constitucional austríaco se espalhou na Europa.

\section{A JURISDIÇÃO CONSTITUCIONAL PARA KELSEN}

A proteção da Constituição ocorre por meio da jurisdição constitucional. Para tanto, é imprescindivel que haja um órgão, independente dos demais poderes que garanta de forma objetiva a Constituição. O parlamento e o governo devem ser controlados pela jurisdição constitucional.

A proteção pode ocorrer por meio de prevenção, que é a existência do próprio Tribunal e de forma repressiva, por meio de processo que garantam a anulação de atos irregulares, uma vez que é por meio da anulação de atos contrários à Constituição, que se torna mais eficaz a garantia constitucional.

Este órgão não exerce uma "verdadeira função jurisdicional", uma vez que ao anular leis inconstitucionais, se equipara a função de criar uma lei, porque o ato tem caráter geral. Muita embora, sua missão seja apenas jurídica, ou seja, a interpretação Constitucional.

O número dos membros do tribunal deve ser reduzido, podendo, uma parte ser eleita pelo parlamento, após designação de candidatos pelo governo. Outra parte deve ser jurista de profissão, indicados por faculdades de direito do país ou pelo próprio tribunal.

Para Kelsen, o ideal é que não haja influência política no tribunal constitucional. Entretanto, os especialistas podem

\footnotetext{
14 RODRÍGEUZ. Pinero “El Tribunal Constitucional Espanol. Disponível http:// biblio.juridicas.unam.mx/libros/1/229/2.pdf ; Acessado em 03/05/2014.
} 


\section{DA DISTINÇÃO ENTRE FILOSOFIA DO DIREITO E CIÊNCIA JURÍDICA}

conscientemente ou inconscientemente ser influenciados por consideração política. Deste modo, é preferivel que não haja influência oculta e incontrolável. Kelsen admite a indicação de membros pelo parlamento, assim, os partidos participam de forma legítima, por via do parlamento, que elege parte dos membros. O tribunal está composto por especialistas e indicações políticas.

O objeto do controle são as leis (atos demandados do poder legislativo central ou dos estados federados). Também pode ser objeto de controle atos do parlamento, como o regulamento ou mesmo a votação do orçamento, além de resoluções e de regimentos.

Podem também ser objeto de controle, os regulamentos com força de leis, ou seja, os atos imediatamente subordinados à Constituição, principalmente, os atos editados em situação extraordinária (regulamentos de necessidade).

Quanto aos regulamentos complementários, verifica-se que a sua irregularidade está mais ligada ao controle de legalidade, sendo, apenas de forma mediata, objeto de controle de constitucionalidade.

Ocorre que todos os atos estão subordinados à Constituição, devendo-se, no entanto, fazer uma distinção entre os atos gerais, por exemplo, as resoluções de conselhos municipais, e os atos individuais, como a aprovação de uma autoridade pública ou estatutos de uma sociedade. Estes últimos não são passiveis de controle.

Os tratados internacionais também são objeto de controle de constitucionalidade, sendo de interesse político que os tratados estejam de acordo com a Constituição, não existindo regra no direito internacional que se oponha a este controle.

Quanto à inicialidade do procedimento, entre várias soluções, Kelsen indica as seguintes formas:

a) Obrigatoriedade de as autoridades públicas, que tenham dúvida sobre a Constituição de uma norma, 
demandar ao Tribunal para exame e eventual anulação da norma.

b) Recurso de inconstitucionalidade, permitindo às partes, em processo judicial ou administrativo que suscitem dúvida de norma aplicável.

c) Os estados federados e o governo federal podem requerer o controle de constitucionalidade, para discutir questões referentes às competências estabelecidas na Constituição sobre os estados federados.

d) Criação da figura do defensor da Constituição, sendo uma instituição independente, similar ao ministério público. Tal figura seria obrigada a agir de ofício.

e) A minoria qualificada do parlamento.

f) O Tribunal, de ofício, quando tiver dúvida sobre norma, por exemplo, ao verificar a constitucionalidade de um regulamento, o Tribunal nota que há irregularidade na lei que o regulamento objeto de análise contrária.

\section{DIREITO COMPARADO: BREVES NOTAS SOBRE OUTROS SISTEMAS DE CONTROLE DE CONSTITUCIONALIDADE}

\subsection{MODELO NORTE-AMERICANO}

A Suprema Corte americana é composta por 9 juízes, todos são indicados pelo presidente. As indicações devem ser aprovadas pelo Senado. O presidente da Corte é indicado pelo presidente da República e ocupa o cargo de forma vitalícia ${ }^{15}$.

\footnotetext{
15 "Mas ao contrário do modelo brasileiro, a indicação e a aprovação dos membros da Suprema Corte não é um processo meramente formal. Cada indicação é um acontecimento histórico que mobiliza todos os setores da opinião pública e os meios de comunicação social. Há uma intensa expectativa quanto à indicação presidencial. Especula-se junto à sociedade civil o perfil desejado para o novo ministro. Anunciado o nome pelo Presidente da República, a vida e a carreira do novo ministro são imediatamente tornadas públicas pela mídia, que passa a colher uma eclosão de manifes- 


\section{DA DISTINÇÃO ENTRE FILOSOFIA DO DIREITO E CIÊNCIA JURÍDICA}

O modelo de controle de constitucionalidade norte americano $^{16}$ é realizado apenas em casos concretos, existindo ainda princípios que norteiam a atividade jurisdicional como o fato de a corte somente se pronunciar sobre questão constitucional quando for solicitado de forma expressar.

O sistema é de competência difusa, ou seja, todos os tribunais - sejam estaduais ou federais - analisam a questão da constitucionalidade prevalecendo as decisões da Suprema Corte. O objeto do controle são todos os atos normativos. A lei não é anulada, simplesmente é "não lei" e a corte não solicita nenhuma declaração do Congresso sobre a lei.

No sistema americano funciona a forma incidental, sendo a injunção e o juízo declaratório os principais meios. Em qualquer demanda judicial, as partes ou o próprio juiz podem arguir a inconstitucionalidade da lei aplicada.

A eficácia das decisões são apenas inter partes, situação que não traz nenhuma insegurança jurídica, porque a regra no common law é a obediência ao precedente, existindo a figura do stare decisis. O princípio determina que stare decisis et non quieta movere, ou seja, estar com as coisas decididas e não mover as coisas quietas ${ }^{17}$.

tações públicas sobre a indicação". ATAIDE. Vicente de Paula. A Seleção dos Juizes da Suprema Corte Norte-Americana. Disponivel http://www. ibrajus.org.br/revista/artigo.asp?idArtigo $=55$. Site do Instituto Brasileiro de Administração do Sistema Judiciário.

16 O sistema americano passou por três fases. A primeira até 1880 , onde havia uma preocupação referente à defesa da unidade dos EUA e às questão federativas. A segunda fase de 1880 a 1935-1937, a preocupação é referente às questões de ordem liberal e a sua autoridade frente ao poder legislativo. Em uma terceira fase a partir de 1954 salvaguarda da liberdade política e da igualdade racial. BARACHO, José Alfredo de Oliveira. op. cit., p. 97.

${ }^{17}$ BARACHO JÚNIOR, José Alfredo de Oliveira. A interpretação dos direitos fundamentais na Suprema Corte dos EUA e no Supremo Tribunal Federal. In: SAMPAIO, José Adércio Leite. (Coord.). Jurisdição constitucional e direitos fundamentais. Belo Horizonte: Del Rey, 2003. p. 315-345. 


\subsection{MODELO ALEMÃO}

A Suprema Corte alemã é composta por 2 senados, cada um tem 8 juízes eleitos, uma metade pelo parlamento federal e a outra metade pelo conselho federal (órgão que representa os estados federados). Os juízes são eleitos para mandato de 12 anos. A reeleição é proibida e aos 68 anos, o juiz é obrigado a deixar o cargo.

Há controle de constitucionalidade preventivo nos seguintes casos: a) as leis que aprovam os tratados podem ser submetidas ao controle de constitucionalidade, a pedido dos governadores do estado e $1 / 3$ do parlamento alemão; b) controle do veto do presidente, o tribunal pode ser acionado quando o presidente da República se recusa a promulgar a lei. Aqui o tribunal verifica a constitucionalidade dos motivos de negativa do presidente; c) uma lei que entrará em vigor poderá ficar suspensa, até que o tribunal verifique sua constitucionalidade.

O tribunal faz o controle repressivo, nas seguintes situações; a) por via de ação, ocorre em relação a todas as categorias de normas, podendo ser instado pelos governados dos estados ou 1/3 dos membros do parlamento. Os entes legitimados podem requerer a declaração de constitucionalidade ou de inconstitucionalidade da norma; b) remessa dos tribunais, os tribunais dos estados podem requerer, de forma incidental, que a corte se pronuncie quando há dúvida sobre a constitucionalidade de uma norma; e, c) recurso constitucional, qualquer cidadão que tiver direitos fundamentais lesados, por uma norma, pode requerer ao tribunal a anulação da norma.

\subsection{MODELO FRANCÊS}

Engenhoso lastro político-jurídico ${ }^{18}$ da República francesa é o Conselho Constitucional, composto por nove membros,

18 De acordo com a classificação de José Afonso o controle é político. SILVA, J. A. Curso de Direito Constitucional Positivo. São Paulo: Malheiros, 2005. p. 49 . 
com mandato de 9 anos, que são nomeados pelos presidentes da República, da Assembleia Nacional e do Senado (três membros, cada) ${ }^{19}$. É vedada a recondução aos cargos.

O Conselho Constitucional antecipa o controle de constitucionalidade das leis, antes mesmo da sua promulgação. Qualquer disposição declarada inconstitucional não pode ser promulgada nem aplicada. As decisões do Conselho Constitucional são irrecorriveis e devem ser acatadas pelos poderes públicos e todas as autoridades administrativas e jurisdicionais ${ }^{20}$.

O controle prévio é obrigatório em casos de leis orgânicas (que regulam as instituições) e regulamentos internos das assembleias parlamentares, além de regulamentos das assembleias parlamentares e leis que dispõem sobre a organização dos poderes públicos, sobre reformas relativas à política econômica, social ou ambiental, sobre os serviços públicos e ratificação de tratados. São imunes de controle as leis referendadas e as emendas constitucionais.

As demais leis são submetidas ao Conselho, antes de sua promulgação, a pedido do presidente da República, do primeiro-ministro, do presidente da Assembleia Nacional, do presidente do Senado ou por sessenta deputados ou sessenta senadores.

Por fim, quando no âmbito de um processo judicial for suscitado que a lei ameaça direitos e liberdades garantidos pela Constituição. Neste caso, o Conselho será provocado pelo Conselho de Estado (órgão que julga em última instância a legalidade dos atos administrativos) ou pelo do Supremo Tribunal.

O poder judiciário não tem competência de controle de constitucionalidade, nem difuso nem abstrato, a competência

19 Os ex-presidentes podem fazer parte do Conselho como membros vitalícios.

20 ARAÚJO, Marilene A Constituição francesa de 1958 e a liberdade de comunicação audiovisual e da Internet, Maria Garcia (cord.) REVISTA DE DIREITO CONSTITUCIONAL E INTERNACIONAL - VOL.75 Ano 19 - abril-junho 2011 
é exclusiva do Conselho Constitucional, órgão independente que não é vinculado a nenhum dos três poderes.

\section{ANTECEDENTES HISTÓRICOS NO BRASIL}

A primeira assembleia constituinte brasileira, de 1823, antes de ser dissolvida por D. Pedro I, trata da constitucionalidade das leis em seu "projeto de Constituição". O artigo 266 dispõe que "todas as leis existentes, contrárias à letra e ao espírito da presente Constituição, são de nenhum valor" ${ }^{21}$.

A Constituição de 1891, após a adoção do regime republicano, inspirada no sistema norte-americano, confere ao Poder Judiciário o controle da constitucionalidade das leis. Assim, a Constituição, em seu artigo 59, alíneas "a" e "b" dispõe que:

Compete ao Supremo Tribunal Federal:-processar e julgar originária e privativamente: $1^{\circ}$ - Das sentenças das Justiças dos Estados, em última instância, haverá recurso para o Supremo Tribunal Federal- a) quando se questionar sobre a validade, ou a aplicação de tratados e leis federais, e a decisão do Tribunal do Estado forem contra ela; b) quando se contestar a validade de leis ou de atos dos Governos dos Estados em face da Constituição, ou das leis federais, e a decisão do Tribunal do Estado considerar válidos esses atos, ou essas leis impugnadas

A Constituição de 1934 mantém a redação da Constituição anterior, mas, em seu artigo 179, estabelece quórum mínimo para o Supremo Tribunal declarar a inconstitucionalidade das leis. Ao senado, nos termos do artigo 91, inciso IV, é conferido poderes para suspender a execução da lei declarada inconstitucional pelo Judiciário.

A Constituição de 1934 outorga competência ao Procurador Geral da República para requerer junto ao Supremo Tribunal a declaração de inconstitucionalidade de lei estadual

21 Ainda o projeto colocava o Poder legislativo como órgão responsável por "Velar na guarda da Constituição, e observância das Leis" inciso X do artigo 41.

18 - Revista do Curso de Direito da Faculdade de Humanidades e Direito, v. 14, n. 14, 2017 


\section{DA DISTINÇÃO ENTRE FILOSOFIA DO DIREITO E CIÊNCIA JURÍDICA}

que ferir princípio constitucional, como a forma de república representativa, a independência e coordenação dos poderes. Neste caso, pode ocorrer intervenção federal.

$\mathrm{Na}$ Constituição de 1937, fruto de uma ditadura, a novidade é a declaração de inconstitucionalidade passar pelo crivo do presidente da República, para fins de bem-estar do povo e para a promoção ou defesa do interesse nacional.

Após declaração de inconstitucionalidade, o presidente submete à lei ao exame do parlamento, que confirmando os termos da lei, torna sem efeito a decisão do tribunal. O presidente tornar-se uma instância recursal em questão constitucional.

A Constituição de 1946 revigora os princípios da Constituição de 1934, mantendo o controle de via de exceção, os recursos extraordinários e a competência do Senado para suspender as leis ou decretos declarados inconstitucionais pelo Supremo. Ainda mantém a representação interventiva.

Assim, o Procurador Geral da República tem o poder de arguir inconstitucionalidade, não em tese, mas quando a inconstitucionalidade for fundamento para a intervenção.

A emenda constitucional de 1965 amplia o instituto da declaração de inconstitucionalidade, inaugurando o instituto da ação direta para declarar inconstitucionalidade de lei em tese. A Constituição de 1946 inclui a competência do Supremo Tribunal Federal de julgar originariamente a representação de inconstitucionalidade da lei proposta pelo Procurador Geral da República.

A mesma emenda dispõe ainda que "a lei poderá estabelecer processo, de competência originária do Tribunal de Justiça, para declaração de inconstitucionalidade de lei ou ato de Município em conflito com a Constituição de Estado".

A Constituição de 1967/69 praticamente mantém as disposições anteriores, apenas suprime a competência dos Tribunais de Justiça dos Estados para realizar o controle de leis ou atos municipais conflitantes com as constituições estaduais. 
Uma emenda de 1977 inclui no rol de competências do Supremo Tribunal Federal, a competência para julgar representações do Procurador Geral da República contra lei estadual ou federal, bem como o pedido de medida cautelar nas representações oferecidas.

\section{SISTEMA DE CONTROLE DE CONSTITUCIONALIDADE BRASILEIRO}

Como verificado, no Brasil o controle de constitucionalidade existe desde 1891, na Constituição republicana de forma incidental. A Constituição de 1946, após a emenda constitucional de 1964, inaugura o controle abstrato e o concentrado. Mas, pode-se afirmar que com a Constituição de 1988, ocorre uma verdadeira expansão na jurisdição constitucional, com a ampliação do controle concentrado.

O princípio da supremacia da Constituição é o que embasa o controle de constitucionalidade dos atos normativos infraconstitucionais. É a partir do controle de constitucionalidade que se garante a eficácia da Constituição, assegurando-se sua observância, aplicação, e conservação.

A Constituição brasileira dispõe sobre o controle de constitucionalidade por via difusa e por via concentrada. $\mathrm{O}$ controle difuso é exercido por todo o Poder Judiciário. Neste caso, qualquer parte no processo ou interessado pode arguir a inconstitucionalidade, sendo que a decisão que declara o ato normativo inconstitucional surte efeitos apenas para o caso concreto do objeto da demanda.

O caso concreto discutido por via difusa pode ser discutido no âmbito do Supremo Tribunal Federal quer seja em razão de competência originária, quer seja por meio de recurso, sendo necessária a maioria absoluta dos membros do Supremo ou dos órgãos especiais.

Desde a Constituição de 1934, o sistema brasileiro de controle difuso tem a possibilidade de que o Senado Federal, por meio de resolução, suspenda a execução da norma, após 
comunicação feita pelo Supremo à casa legislativa (artigo 52, $\mathrm{X}$ da $\mathrm{CF}$ ).

Sobre a questão, sempre há discussão sobre o poder exercido pelo Senado. Vidal Serrano e Luiz Alberto David Araujo defendem que o poder exercido pelo Senado é discricionário, por se tratar de politica legislativa.

Em se tratando de exercício discricionário, o ato é típico de uma decisão e não de mera publicidade, sendo, portanto os seus efeitos ex nunc ${ }^{22}$. Recentemente, o Supremo Tribunal julgou a reclamação 4335 e segundo o voto do relator ${ }^{23}$ :

É inegável, por conseguinte, que, atualmente, a força expansiva das decisões do Supremo Tribunal Federal, mesmo quando tomadas em casos concretos, não decorre apenas e tão somente de resolução do Senado, nas hipóteses de que trata o art. 52, $\mathrm{X}$ da Constituição. É fenômeno que está se universalizando, por força de todo um conjunto normativo constitucional e infraconstitucional, direcionado a conferir racionalidade e efetividade às decisões dos tribunais superiores e, como não poderia deixar de ser, especialmente os da Corte Suprema."

\subsection{SISTEMA CONCENTRADO}

O sistema brasileiro de controle de constitucionalidade contempla o controle concentrado da constitucionalidade de atos normativos federais e estaduais. Dentre as espécies de ações utilizadas para o controle concentrado tem-se a ação direta de constitucionalidade ou inconstitucionalidade e a arguição de descumprimento de preceito constitucional. Tais ações estão previstas na Constituição federal e estão regulamentadas nas leis 9.868/99 e 9882/1999.

O STF já decidiu que não podem ser objeto de controle concentrado: a) norma constitucional originária; b) nos cha-

22 ARAUJO, Luz Alberto David, SERRANO, Vidal. Curso de Direito Constitucional. São Paulo: Verbatim. 2012.p. 63-64.

${ }^{23}$ Íntegra do voto do ministro Teori Zavascki em ação sobre progressão de regime. Disponivel : http://www.stf.jus.br/portal/cms/listarNoticiaSTF. asp. Acessado em 05 de maio de 2014. 
mados atos de efeitos concretos. Neste caso, muito embora a norma seja formalmente uma lei, o seu conteúdo não é abstrato, porque produzem efeitos concretos, ex. a Lei de Orçamento $^{24}$. c) Não cabe controle de constitucionalidade de atos normativos anteriores à $\mathrm{CF}$ de 88 , uma vez que trata de ato que não foi recepcionado pela Constituição. O STF reconhece, neste caso, a carência da ação ${ }^{25}$. d) Atos normativos ou leis revogadas ou que são revogados no curso da ação. e) Regulamentos editados para execução de lei, uma vez que neste caso trata-se de controle de legalidade.

É possivel declaração de inconstitucionalidade de dispositivos do ato normativo atacado que não são objeto do pedido inicial, mas que por consequência lógica podem ser alcançados por decisão proferida nos autos da ADIN.

\subsection{AÇÃO DIRETA DE INCONSTITUCIONALIDADE}

A Constituição prevê a possibilidade de três tipos de ação direta de inconstitucionalidade, a genérica, a por omissão e a interventiva.

\subsubsection{AÇÃO DIRETA DE INCONSTITUCIONALIDADE GENÉRICA}

O objeto da ação direita de constitucionalidade e ação direta de inconstitucionalidade são as emendas constitucionais, leis complementares, leis ordinárias, medidas provisórias ${ }^{26}$,

${ }^{24}$ Gilmar Mendes critica a posição do STF por considerar que "Se a Constituição submete a lei ao processo de controle abstrato, até por ser este o meio próprio de inovação na ordem jurídica e o instrumento adequado de concretização da ordem constitucional, não parece admissível que o interprete debilite essa garantia da Constituição, isentando um número elevado de atos aprovados sob a forma de lei do controle abstrato de normas e, muito provavelmente, de qualquer forma de controle". Jurisdição Constitucional. São Paulo: Saraiva: 2013.

25 Gilmar Mendes considera possivel e coerente que o STF aceite a lei-pré constitucional, no caso de Ação Declaratória de Constitucionalidade Gilmar Mendes, Jurisdição constitucional p. 261.

26 Não prejudica a ação quando a medida provisória é convertida em lei sem alteração. Quando há alteração na conversão da medida, não pode haver aditamento à inicial. Pode haver aplicação de procedimento sumário. 


\section{DA DISTINÇÃO ENTRE FILOSOFIA DO DIREITO E CIÊNCIA JURÍDICA}

leis delegadas, decretos legislativos, decretos do executivo que ratificam os tratados e convenções, e resoluções, os atos do Poder Executivo, regimentos internos dos Tribunais e das Assembleias Legislativas, constituições e leis estaduais ou do Distrito Federal. No caso do Distrito Federal, estão excluídas do controle as leis cujo conteúdo seja pertinente ao exercício de competências atribuídas ao município.

São considerados atos normativos aqueles editados por pessoas jurídicas de direito público, normas de caráter autônomo, decreto ${ }^{27}$ e pareceres ${ }^{28}$ da Consultoria Geral da República que são devidamente aprovados pelo Presidente da República.

A ação direta de inconstitucionalidade possui conteúdo declaratório, sendo que a competência para processar a ação direta de inconstitucionalidade é exclusiva do Supremo Tribunal Federal.

O rol de legitimados está previsto no artigo $103^{29}$, sendo uma legitimação autônoma, pois não há nenhum interesse individual subjetivo que seja objeto da ADIN. A legitimação é disjuntiva e concorrente, pois qualquer um dos co-legitimados pode ajuizar a ADIN, isoladamente ou em litisconsórcio facultativo.

Dentre os legitimados existem os neutros ou universais, isto é, aqueles que o Supremo aceita sem exigir quaisquer requisitos e os interessados ${ }^{30}$, que são os que necessitam demostrar pertinência temática.

\footnotetext{
${ }^{27}$ ADI 2155 - Ação Direta de inconstitucionalidade. Decisão: Preliminarmente, o Tribunal, por unanimidade, rejeitou a articulação de não-cabimento da ação direta de inconstitucionalidade, por se tratar de decreto autônomo 15/02/2001

${ }^{28}$ ADI 460/DF. Rel Sepúlveda Pertence, FJ de 10-5-1991.

29 o Presidente da República; a Mesa do Senado Federal; a Mesa da Câmara dos Deputados; IV - a Mesa de Assembléia Legislativa ou da Câmara Legislativa do Distrito Federal; V - o Governador de Estado ou do Distrito Federal; VI - o Procurador-Geral da República; VII - o Conselho Federal da Ordem dos Advogados do Brasil; VIII - partido político com representação no Congresso Nacional; IX - confederação sindical ou entidade de classe de âmbito nacional).

30 Classificação feita por Clemerson M. Clève.
} 
São considerados neutros ou universais, o presidente da República, a mesa do senado federal, a câmara dos deputados, procurador da República, o Conselho Federal da Ordem dos Advogados do Brasil, os partidos políticos com representação no Congresso nacional.

\subsubsection{AUTORES INTERESSADOS E PERTINÊNCIA TEMÁTICA}

Em se tratando de confederação sindical ou entidades de classe de âmbito nacional deve ser demonstrada se há relação de pertinência entre a atividade de representação e o objeto da ação. Da mesma forma, a jurisprudência do STF considera que o Governador ou a Assembleia Legislativa deve demonstrar relevância na pretensão formulada ${ }^{31}$.

Após ampla discussão ocorrida na Suprema Corte, o tribunal optou por considerar que apenas as organizações sindicais, na forma do artigo 535 da CLT, ${ }^{32}$ podem ser consideradas parte legítima para ingressar com ação de controle de constitucionalidade.

Em relação às entidades de classe de âmbito nacional devem ter membros, ${ }^{33}$ em pelo menos 9 Estados da Federação, sendo tal requisito aplicação analógica da lei orgânica de partidos políticos.

As entidades devem ter como membros associados do mesmo segmento ${ }^{34}$, não podendo ser entidades que representem segmentos da sociedade civil $^{35}$. O Supremo, em decisão

\footnotetext{
31 A jurisprudência do Supremo Tribunal entende que para um governador impugnar um ato é necessária a demonstração de pertinência da pretensão. Assim, o governador deve demonstrar que o Estado tem interesse na discussão, como no caso de reflexos tributários. É o governador que firma a inicial, juntamente com o procurador geral do Estado ou com outro advogado.

32 Art. 535 - As Confederações organizar-se-ão com o mínimo de 3 (três) federações e terão sede na Capital da República.

33 Gilmar Mendes, Jurisdição constitucional p. 187.

34 ADIN 108- DF.

35 ADIN 894-DF.
}

24 - Revista do Curso de Direito da Faculdade de Humanidades e Direito, v. 14, n. 14, 2017 
datada de 2004, entendeu que "associação de associação" é parte legitimada ${ }^{36}$.

Em decorrência das decisões do Supremo Tribunal Federal, os legitimados, confederação sindical, entidade de classe de âmbito nacional, Governador de Estado ou do Distrito Federal, a Mesa de Assembleia Legislativa ou da Câmara Legislativa do Distrito Federal, necessitam demonstrar pertinência temática.

\subsubsection{O CONTROLE DE INCONSTITUCIONALIDADE POR OMISSÃO}

O controle de inconstitucionalidade por omissão pode ser suscitado quando não houver elaboração de atos legislativos ou normativos, impossibilitando o cumprimento de preceitos constitucionais. O controle pode eventualmente alcançar o poder regulamentar de autoridade administrativa, quando a lei determina a realização do ato, necessitando do mesmo para ser aplicada.

A decisão que julgar a ação de inconstitucionalidade por omissão não poderá editar o ato normativo, sob pena, de violação ao princípio da separação dos poderes, podendo o Poder Judiciário determinar prazo para adoção de providências, conforme determina o artigo 103 , paragrafo $2^{\circ}$ da Constituição ${ }^{37}$.

\subsubsection{AÇÃO DIRETA DE INCONSTITUCIONALIDADE INTERVENTIVA}

A Constituição prevê situações em que poderá haver intervenção da União nos Estados e Distrito Federal para assegurar a observância dos princípios constitucionais referentes à forma da república, ao sistema representativo, ao regime democrático, aos direitos da pessoa humana, à autonomia

36 ADIN 3153

$37 \S 2^{\circ}$ - Declarada a inconstitucionalidade por omissão de medida para tornar efetiva norma constitucional, será dada ciência ao Poder competente para a adoção das providências necessárias e, em se tratando de órgão administrativo, para fazê-lo em trinta dias. 
municipal, à prestação de contas da administração, à aplicação do mínimo exigido da receita resultante de impostos estaduais, compreendida a proveniente de transferências, na manutenção do ensino e saúde. São estes os considerados princípios sensíveis.

Assim, diante de ato que viole os princípios sensíveis, o Procurador Geral da República ingressa com representação. O STF se entender que há os pressupostos, solicita que o Presidente da República realize a intervenção. A Constituição, em seu artigo 36, III, fala em representação, porém parte da doutrina entende que é uma verdadeira Ação de controle de normas frente à Constituição.

\subsection{AÇÃO DECLARATÓRIA DE CONSTITUCIONALIDA- $\mathrm{DE}$ - (ADECON)}

A ação declaratória de constitucionalidade foi prevista a partir da emenda constitucional 03/93. O objeto da ação são as leis e os atos normativos federais e estaduais e o seu pressuposto é a ocorrência de controvérsia judicial, (art. 14, III, da lei 9868) sobre a constitucionalidade de determinada norma. A competência para processar e julgar é do STF, sendo que os legitimados são os mesmos da ADIN.

Na ADECON não há a intervenção do Advogado Geral da União, entretanto, é obrigatória a intervenção do Procurador Geral da República, por força do disposto no parágrafo $1^{\circ}$, do art. 103 da Constituição. Os efeitos da sentença proferida, em sede de ADECON, são os mesmos que da ADIn.

A necessidade da controvérsia se demonstra em razão da segurança jurídica, bem como em razão da própria presunção de constitucionalidade da lei. A grande quantidade de ações no âmbito do poder judiciário traz incerteza e insegurança em relação à lei e coloca a própria atribuição do legislativo em constante contingência.

É para amenizar os efeitos de tal situação que a ação de declaração de constitucionalidade pode ser manejada, sendo, 
portanto indispensável para que a ação seja conhecida se demonstre a controvérsia em relação à $l \mathrm{i}^{38}$.

\subsection{ARGUIÇÃO DE DESCUMPRIMENTO DE PRECEI-} TO FUNDAMENTAL

A argüição de descumprimento de preceito fundamental (ADPF) está prevista no parágrafo $1^{\circ}$ do art. 102 e regulamentada pela lei 9.882/99. A Constituição assim dispõe:

$\S 1 .^{\circ} \mathrm{A}$ argüição de descumprimento de preceito fundamental, decorrente desta Constituição, será apreciada pelo Supremo Tribunal Federal, na forma da lei.

A lei 9882/99, ao seu turno, estabelece que:

Art. 1ㅇ A argüição prevista no $\S 1$ 일 do art. 102 da Constituição Federal será proposta perante o Supremo Tribunal Federal, e terá por objeto evitar ou reparar lesão a preceito fundamental, resultante de ato do Poder Público.

Parágrafo único. Caberá também argüição de descumprimento de preceito fundamental:

I - quando for relevante o fundamento da controvérsia constitucional sobre lei ou ato normativo federal, estadual ou municipal, incluídos os anteriores à Constituição;

O legislador ordinário inovou ao estabelecer uma nova modalidade de arguição de inconstitucionalidade prevista no parágrafo $1^{\circ}$ do artigo $1^{\circ}$ da lei, criando uma arguição incidental não prevista na Constituição. Parte da doutrina questiona a constitucionalidade do dispositivo, sobretudo pelo fato de caber à arguição em relação à lei ou ato normativo federal, estadual ou municipal, incluídos os anteriores à Constituição ${ }^{39}$.

\footnotetext{
${ }^{38}$ Há criticas na doutrina em relação a ADECON pelo fatos de se tratar de processo unilateral, da desnecessidade do instituto porque as leis gozam de presunção de constitucionalidade e pelo fato de vincularem os juízes.

39 ARAUJO, Luz Alberto David, SERRANO, Vidal. Curso de Direito Constitucional. São Paulo: Verbatim. 2012.p. 86-87
} 
Em relação ao preceito fundamental, em razão de inexistência de explicação legislativa, a construção é interpretativa. Parte da doutrina entende que seriam os fundamentos de uma Constituição, sendo aquelas normas imprescindiveis ao conteúdo de uma Constituição, ou seja, a estruturação do Estado, (federalismo e princípio republicano), a divisão e atribuição de poderes, os direitos fundamentais ${ }^{40}$.

Maria Garcia ${ }^{41}$ considera problemática a interpretação conferida pela lei do termo preceito fundamento fundamental, em razão do termo "decorrente" contido na Constituição:

“o termo decorrente (decursivo, derivado, consequente, segundo
o Dicionário Aurélio) faz concluir, primeiramente, pela possibi-
lidade de localização do preceito externamente à Constituição.
Porquanto, se é decorrente da Constituição não deverá estar,
necessariamente, contido na Constituição. Não expressamente.
E, neste particular, obrigatória se torna a lembrança do dis-
posto no $\S 2^{\circ}$ do art. $5^{\circ}$, o qual admite a existência de 'outros
direitos e garantias', além daqueles expressos na Constituição,
'decorrentes do regime e dos princípios por ela adotados' (ou
dos tratados internacionais firmados)."

O STF já decidiu que a ação pode ter por objeto atos normativos ou não de efeitos concretos ou singulares, incluso decisões judiciais, (STF ADPF 101), atos ou leis pré-constitucionais, leis já revogadas (STF ADPF 33). No mais, já se decidiu a possibilidade para viabilizar a concretização de políticas públicas previstas na Constituição (ADPF 45) ${ }^{42}$.

Os legitimados são os mesmos da Ação Direta de Inconstitucionalidade. O Ministério Público deverá intervir no feito,

40 ARAUJO, Luz Alberto David, SERRANO, Vidal. Curso de Direito Constitucional. São Paulo: Verbatim. 2012.p. 86-87

41 GARCIA, M. Arguição de descumprimento: direito do cidadão. Revista de Direito Constitucional e Internacional. julho-setembro de 2000, n. ${ }^{\circ}$ 32, p. 103

42 COSTA, Aldo de Campos. ADPF pode evitar ou reparar dano a preceito fundamental. http://www.conjur.com.br/2013-mar-27/toda-prova-adpf-usada-evitar-ou-reparar-dano-preceito-fundamental 


\section{DA DISTINÇÃO ENTRE FILOSOFIA DO DIREITO E CIÊNCIA JURÍDICA}

não existindo regulação de intervenção, podendo o relator admitir apresentação de memoriais por parte de interessados no processo, na condição de amicus curiae.

Maria Garcia, ao criticar o teor da lei que regulamentou o instituto, entende que a legitima titularidade do exercício da ação não poderia ter sido retirada do cidadão ${ }^{43}$.

Outra polêmica existente na doutrina e na jurisprudência é sobre o caráter subsidiário conferido a ADPF, pela lei (artigo $4^{\circ}$, parágrafo $1^{\circ}$ ) ${ }^{44}$.

Os críticos consideram que a lei ultrapassa o quanto determinado pela Constituição. Entretanto, a posição majoritária do STF é no sentido de que o ajuizamento da ADPF rege-se pelo princípio da subsidiariedade, podendo ser manejada quando não há outro meio eficaz.

\subsection{AMICUS CURIAE}

O amicus curiae é modalidade interventiva, segundo a qual, determinado órgão ou entidade que tenha interesse no julgamento do processo possa de alguma forma contribuir para o julgamento. Tal figura, nos termos da lei, é admitida no controle de constitucionalidade concentrado ${ }^{45}$.

Para atuar como amicus curiae deve ser demonstrada a relevância da matéria debatida e a representatividade. A admissão do amicus curiae no processo é feita de forma discricionária pelo relator, não restando muitas dúvidas em relação ao rol de legitimados previsto no artigo 103 da Constituição. De resto, a questão é problemática, porque é resolvida no caso concreto.

43 GARCIA, M. Arguição de descumprimento: direito do cidadão. Revista de Direito Constitucional e Internacional. julho-setembro de 2000, n. ${ }^{\circ}$ 32, p. 103

$44 \S 1$ Não será admitida argüição de descumprimento de preceito fundamental quando houver qualquer outro meio eficaz de sanar a lesividade.

$45 \S 2 \circ \mathrm{O}$ relator, considerando a relevância da matéria e a representatividade dos postulantes, poderá, por despacho irrecorrivel, admitir, observado o prazo fixado no parágrafo anterior, a manifestação de outros órgãos ou entidades. 
Para Cassio Scarpinella Bueno, a função do amicus curiae é:

Levar, espontaneamente ou quando provocado pelo magistrado, elementos de fato e/ou de direito que de alguma forma relacionam-se intimamente com a matéria posta para julgamento. É por isto que me refiro insistentemente ao amicus curiae como um "portador de interesses institucionais" a juízo. Ele atua, no melhor sentido do fiscal da lei, como um elemento que, ao assegurar a imparcialidade do magistrado por manter a indispensável "terzietà" do juiz com o fato ou o contexto a ser julgado, municia-o com os elementos mais importantes e relevantes para o proferimento de uma decisão ótima que, repito, de uma forma ou de outra atingirá interesses que não estão direta e pessoalmente colocados (e,por isto mesmo, defendidos) em juízo. ${ }^{46}$

\subsection{MEDIDA CAUTELAR}

Em todo o processo objetivo pode ocorrer a concessão de medida cautelar. A lei $9868^{47}$ disciplina a concessão de cautelar nas ADIn e ADECON, excetuadas as exceções nos casos de recesso forense, a concessão da medida deve ser aprovada pela maioria absoluta do Plenário.

No caso da ADPF, o artigo $5^{\circ}$ da lei 9.882/99 determina que a medida pode ser concedida por maioria absoluta dos membros do tribunal e no caso de extrema urgência ou perigo de lesão grave, ou em período de recesso, poderá o relator conceder a liminar, ad referendum do Tribunal Pleno.

A liminar poderá consistir na determinação de que Juízes e Tribunais suspendam o andamento de processo ou os efeitos de decisões judiciais que tenham relação com a matéria objeto da ADPF, salvo as decorrentes da coisa julgada.

\footnotetext{
${ }^{46}$ Cassio Scarpinella Bueno quatro perguntas e quatro respostas sobre o amicus curiae. Disponivel: http://www.scarpinellabueno.com.br/Textos/ Amicus\%20curiae.pdf 1

47 Artigos 10, 12 e 21

30 - Revista do Curso de Direito da Faculdade de Humanidades e Direito, v. 14, n. 14, 2017
} 


\section{DA DISTINÇÃO ENTRE FILOSOFIA DO DIREITO E CIÊNCIA JURÍDICA}

\subsection{MODULAÇÃO DE EFEITOS}

A questão de modulação de efeitos do controle concentrado de constitucionalidade repercute em questões relacionadas à segurança jurídica e à boa-fé. Hans Kelsen defendeu que a decisão em sede de controle de constitucionalidade é de caráter constitutivo, portanto a lei é anulável. O Brasil adotou a teoria americana. Assim entendeu que a decisão é declaratória e afeta a validade da norma, assim há efeitos retroativos.

Ocorre que a lei 9.868/99, em seu artigo 27, estabeleceu que:

"Art. 27. Ao declarar a inconstitucionalidade de lei ou ato normativo, e tendo em vista razões de segurança jurídica ou de excepcional interesse social, poderá o Supremo Tribunal Federal, por maioria de dois terços de seus membros, restringir os efeitos daquela declaração ou decidir que ela só tenha eficácia a partir de seu trânsito em julgado ou de outro momento que venha a ser fixado."

Após a lei 9.882 /99, que igualmente assinalou, em seu art. 11:

Ao declarar a inconstitucionalidade de lei ou ato normativo, no processo de argüição de descumprimento de preceito fundamental, e tendo em vista razões de segurança jurídica ou de excepcional interesse social, poderá o Supremo Tribunal Federal, por maioria de dois terços de seus membros, restringir os efeitos daquela declaração ou decidir que ela só tenha eficácia a partir de seu trânsito em julgado ou de outro momento que venha a ser fixado.

\section{PLURALIDADE NA JURISDIÇÃO CONSTITUCIONAL}

A jurisdição constitucional tem como enfoque principal a interpretação constitucional. A decisão proferida deve enfrentar várias concepções ideológicas, morais e de valores, porque reflete o texto constitucional. Ainda, a decisão tem caráter projetivo, porque a decisão judicial projeta um futuro. 
Peter Häberle, em 1975, abriu para o mundo jurídico um debate sobre os sujeitos ativos da interpretação constitucional, quando publicou, na Alemanha, a obra $A$ sociedade aberta dos intérpretes da Constituição: contribuição para a interpretação pluralista e procedimental da Constituição. Após 22 anos, a obra é publicada no Brasil, mas ainda, depois anos, o debate da Sociedade Aberta dos Intérpretes traz discussões e aprendizado para a teoria da interpretação constitucional.

$\mathrm{Na}$ sociedade aberta dos intérpretes, os participantes do processo judicial (partes, terceiros, peritos, pareceristas) influenciam de forma ativa a interpretação judicial. Grupos de pressões, como sindicatos, igrejas, associações empresariais e civis, dentre outros, considerando a concretização da Constituição no âmbito da administração, do Judiciário e no Legislativo, participam ativamente do processo interpretativo.

Tais processos interpretativos, no ambiente institucional, são evidenciados a partir de consultas públicas, audiências públicas, bem como, no processo de controle de constitucionalidade concentrado brasileiro, através do amicus curiae ${ }^{48}$.

Fora do ambiente institucional, mas que possui relevância, o cidadão aparece como figura importante na estrutura do Estado moderno, pois é o sujeito ativo de direitos e deveres em relação à sua comunidade. A Constituição brasileira, por exemplo, estabelece a cidadania, ao menos figurativamente, como princípio fundamental da estrutura do Estado (art. 1. ${ }^{\circ}$, II, da CF / 1988).

Para Peter Härbele as reflexões sobre o desenvolvimento da jurisdição constitucional devem ter "compromisso com

48 Definido por Cássio Bueno Scarpinella como um terceiro enigmático, no próprio título de sua obra Amicus Curiae no processo civil: um terceiro enigmático. $2^{\circ}$ ed. São Paulo: Saraiva. 2008, amicus curiae pode "ser considerado como auxiliar eventual que colabora em questão de alta relevância social ou politica, ajudando o magistrado na tarefa de interpretar o direito ao caso concreto." FERREIRA, Joana Cristina. O Amicus Curie e a pluralização das ações constitucionais. In OLIVEIRA, Vallisney de Souza. Constituição e Processo Civil. São Paulo: Saraiva. 2008. p. 94. 


\section{DA DISTINÇÃO ENTRE FILOSOFIA DO DIREITO E CIÊNCIA JURÍDICA}

um modelo pluralista, visando à obtenção de instrumentos pluralista de informação e participação". Neste contexto, o autor explica a necessidade de atenção na formação pluralista da composição do próprio tribunal, bem como audiências públicas mais autênticas.

\section{CONSIDERAÇÕES FINAIS}

Em tempos atuais, a Constituição é para o Direito o que garante a sua unidade pela diferenciação do direito constitucional e dos demais direitos (Niklas Luhmann). Não é a toa que debate caloroso aconteceu no século passado, entre Carl Smicht e Hans Kelsen, para definir quem era o soberano que guardava a Constituição - ou seja, quem daria a palavra final sobre a validade da lei em face à Constituição.

Hans Kelsen defendeu a jurisdição constitucional como forma de garantia da eficácia e aplicação da Constituição a ser realizada por órgão técnico. A função principal da jurisdição constitucional é a defesa e a proteção da Constituição.

A grande parte dos países que optaram pela democracia ocidental possui a jurisdição constitucional para defesa da Constituição. A atuação deste órgão suscita discursões em relação à legitimidade de seus membros e de suas decisões.

Essas questões têm feito com que haja uma ampliação de acesso à jurisdição constitucional e a criação de mecanismos para que a comunidade participe da construção da decisão da Corte Constitucional, é o caso do amicus curie. Peter Harbelle tem defendido que o desenvolvimento da jurisdição constitucional deve observar cada vez mais o pluralismo para que haja maior participação democrática.

\section{BIBLIOGRAFIA}

AKAOUKI, Fernando Reverendo Vidal. Jurisdição Constitucional e a Tutela dos Direitos Metaindividuais. São Paulo: Verbatim. 2009.

Almeida, Gregório Assagra de Almeida. Manual das ações constitucionais. Belo Horizonte: Del Rey. 2007.

ARAUJO, Luz Alberto David, SERRANO, Vidal. Curso de Direito Constitucional. São Paulo: Verbatim. 2012 
ARAUJO, Marilene. A sabedoria da multidão e a interpretação constitucional Maria Garcia (cord.) Revista de Direito Constitucional e Internacional - VOL.77 Ano 19 - outubro-dezembro 2011.

ARAÚJO, Marilene. A Constituição francesa de 1958 e a liberdade de comunicação audiovisual e da Internet, Maria Garcia (cord.) REVISTA DE DIREITO CONSTITUCIONAL E INTERNACIONAL - VOL.75 Ano 19 - abril-junho 2011.

ATAIDE, Vicente de Paula. A Seleção dos Juizes da Suprema Corte Norte-Americana. Disponivel http://www.ibrajus.org.br/revista/artigo. asp?idArtigo $=55$. Site do Instituto Brasileiro de Administração do Sistema Judiciário.

BASTOS, Celso Ribeiro. Hermenêutica e Interpretação Constitucional. São Paulo: Celso Bastos Editor: Instituto Brasileiro de Direito Constitucional. 1997.

BASTOS, Celso Ribeiro. Curso de Direito Constitucional. São Paulo: Saraiva. 1988.

BARACHO JÚNIOR, José Alfredo de Oliveira. A interpretação dos direitos fundamentais na Suprema Corte dos EUA e no Supremo Tribunal Federal. In: SAMPAIO, José Adércio Leite. (Coord.). Jurisdição constitucional e direitos fundamentais. Belo Horizonte: Del Rey, 2003.

BARROSO, Luís Roberto. Curso de Direito Constitucional Contemporâneo. São Paulo: Saraiva. 2012.

BONAVIDES, Paulo. Jurisdição constitucional e legitimidade (algumas observações sobre o Brasil) Disponível: http://www.scielo.br/pdf/ea/ v18n51/a07v1851. Acessado em 04/05/2014.

BONAVIDES, Paulo. Curso de Direito Constitucional. São Paulo: Malheiros. 2008.

BUENO, Cassio Scarpinella. Quatro perguntas e quatro respostas sobre o Amicus curiae. Disponivel: http://www.scarpinellabueno.com.br. Acessado em $01 / 06 / 2014$

CANOTILHO, José Joaquim Gomes. Direito Constitucional e Teoria da Constituição. Coimbra: Livraria Almedina. Ed. 3 ${ }^{\text {a }}, 1998$.

CANOTILHO, José Joaquim Gomes. Direito Constitucional. Coimbra: Livraria Almedina. Ed. 5 ${ }^{\mathrm{a}}, 1991$.

CANOTILHO, José Joaquim Gomes. Direito de acesso. À justiça constitucional. Conferência das Jurisdições Constitucionais Dos Países de Língua Portuguesa Luanda. Junho de 2011.

CAPPELLETTI, M. O controle judicial de constitucionalidade das leis no direito comparado. 2 ed. Porto Alegre: Sérgio Antônio Fabris, 1992.

COSTA, Aldo de Campos. ADPF pode evitar ou reparar dano a preceito fundamental. Disponivel. http://www.conjur.com.br/2013-mar-27/toda-prova-adpf-usada-evitar-ou-reparar-dano-preceito-fundamental. Acessado em 05.05.2014.

FAGUNDES, M. Seabra. O controle dos atos administrativo pelo Poder Judiciário. Rio de Janeiro: Forense. Ed. 8. 2010. 


\section{DA DISTINÇÃO ENTRE FILOSOFIA DO DIREITO E CIÊNCIA JURÍDICA}

FERARI, Regina. Efeitos da declaração de inconstitucionalidade. São Paulo: RT: 2005.

FERREIRA, Joana Cristina. O Amicus Curie e a pluralização das ações constitucionais. In . In OLIVEIRA, Vallisney de Souza. Constituição e Processo Civil. São Paulo: Saraiva. 2008.

GARCIA, Maria. Arguição de descumprimento: direito do cidadão. Revista de Direito Constitucional e Internacional. julho-setembro de 2000, n. ${ }^{\circ} 32$.

HÄBERLE, Peter. E1 Estado constitucional. Ciudad del Mexico: Universidad Nacional Autónoma de México. 2003.

HANS, Kelsen. La garantía jurisdiccional de la Constitución (la justicia constitucional). Revista Iberoamericana de Derecho Procesal Constitucional núm. 10, julio-diciembre 2008.

HERRERA, Carlos Miguel. La polémica schmitt-kelsen sobre el guardian de la constitución. Disponivel http://www.udea.edu. Acessado em 04/05/2014 HESSE, Konrad. Escritos de derecho constitucional. Madrid: Centro de Estudos Constitucionales, 1983.

LUHMANn, Niklas. A Constituição como Aquisição Evolutiva. Disponível em: <http://pt.scribd.com/doc/31253250/LUHMANN-Niklas-A-constituicao-como-aquisicao-evolutiva.> Acesso em: 12.06.2014.

MARCELLO, Godinho e DUARTE Fernanda. Notas sobre a suprema corte norte-americana. Disponivel http://www.ajuferjes.org.br/PDF/010artigo_02. pdf p.

MENDES, Gilmar. Jurisdição Constitucional. São Paulo: Saraiva: 2013. MIRANDA, Jorge. Teoria do estado e da Constituição. Rio de Janeiro: Forense, 2002.

OlIVEIRA, Vallisney de Souza. Constituição e Processo Civil. São Paulo: Saraiva. 2008.

PEIXINHO, Manoel Messias. O Princípio da Separação dos Poderes, a Judicialização da Política e Direitos Fundamentais. Revista de Direitos e Garantias Fundamentais, Vitória, n.4, p.13-14, jul/dez.2008.

RODRÍGEUZ, Pinero. "El Tribunal Constitucional Espanol. Disponível http://biblio.juridicas.unam.mx/libros/1/229/2.pdf. Acessado em $03 / 05 / 2014$. 